\title{
Knowledge Level of Cancer Symptoms and Risk Factors in the Gaza Strip: A Cross-sectional Study
}

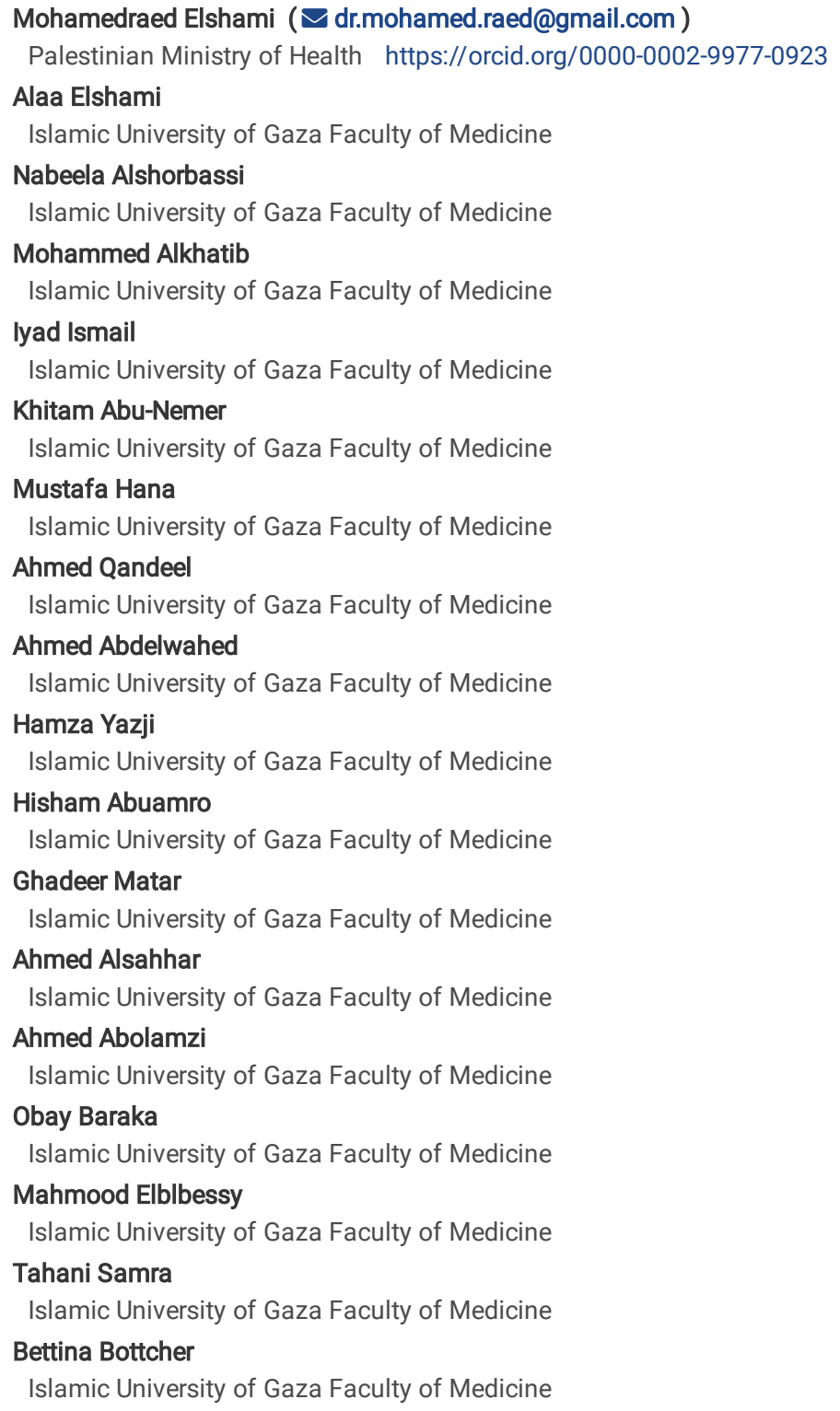

\section{Research article}

Keywords: cancer awareness, adolescent health, cancer risk factors, cancer signs and symptoms, low- and middle-income countries, Gaza, Palestine

Posted Date: December 4th, 2019

DOI: https://doi.org/10.21203/rs.2.18182/v1

License: @ (i) This work is licensed under a Creative Commons Attribution 4.0 International License. Read Full License 


\section{Abstract}

Background In low-income settings, cancer is often diagnosed in advanced stages due to late presentation. Good public awareness of cancer signs and symptoms has a positive impact on the time patients take before they present to healthcare professionals. Therefore, this study examined public knowledge and awareness of cancer signs and symptoms as well as risk factors in the Gaza Strip.

Methods This was a cross-sectional study. Participants were recruited from adult visitors ( $\geq 18$ years) to governmental hospitals covering all five governorates of the Gaza Strip, and adolescent students (15 to 17 years) from ten high schools in corresponding locations. Visitors to oncology departments were excluded. An Arabic version of the Cancer Awareness Measure (CAM) questionnaire was completed in a face-to-face interview. It described demographic data and knowledge of: cancer prevalence, age-related risk, signs and symptoms as well as risk factors both in recall and recognition questions.

Results A total of 2886 participants (out of 3033 ; response rate $=95.2 \%$ ) with a mean age of $24.9 \pm 11.9$ years, completed the questionnaire, including 1457 $(50.5 \%)$ adolescents (781 females; $53.6 \%)$ and $1429(49.5 \%)$ adults (702 females; $49.1 \%)$. About two thirds $(n=1885)$ thought about cancer as unrelated to age. Only 196 participants (6.8\%) identified colorectal cancer as the most common cancer among men. Awareness of cancer signs/symptoms was poor to fair, where 'lump' was most commonly recognized $(n=2227,77.2 \%)$ and 'change of bowel habit' the least $(n=670,23.2 \%)$. Only 217 participants $(7.5 \%)$ had a good level of recognizing risk factors with 'smoking' being the most identified and 'eating less than five portions of fruits and vegetables a day' the least. Adults were persistently better at identifying most cancer signs/symptoms and risk factors than adolescents, except for recalling 'unexplained pain', 'persistent cough/hoarseness', 'non-healing ulcer', 'smoking', and 'eating less than five portions of fruits and vegetables a day'.

Conclusion Public awareness of cancer signs/symptoms and risk factors needs to improve in Gaza to facilitate early presentation and diagnosis. Combining the delivery of public campaigns with tailored education to population groups, including the youth, may increase their knowledge and maintain its impact and sustainability.

\section{Background}

Cancer is responsible for about 9.6 million deaths worldwide in 2018 with $70 \%$ of these occurring in low- and middle-income countries [1]. In the Gaza Strip, the prevalence of cancer was 89.0 per 100,000 general population and the mortality rate was 29.7 per 100,000 general population in 2016 [2]. In fact, cancer is the second leading cause of mortality, after cardiovascular diseases, representing $10.6 \%$ of the total reported deaths [3]. Breast cancer (BC) is the most common cancer representing $20.5 \%$ of all cancer cases and $36.9 \%$ of cancers among females with a prevalence of 18.6 per 100,000 general population [2]. Colorectal cancer (CRC) is the second most common cancer, responsible for $12.6 \%$ of cancers, with a prevalence of 11.5 per 100,000 male population [2]. In fact, $\mathrm{CRC}$ is the most common cancer among males representing $13.2 \%$ of their cancers and the second common cancer, after BC, among females representing $9.1 \%$ of their cancers [3]. The most common cause of cancer deaths in 2017 was lung cancer with $17.3 \%$ of all cancer-related deaths, followed by CRC with $11.8 \%$ and BC by $10.0 \%$ [4]. Poor awareness of cancer symptoms and risk factors resulting in delayed presentation as well as low availability of screening programs and limited access to healthcare services contribute to cancer-related deaths in low- and middle-income countries. All of these factors could play a major role in the high mortality rates [5-9].

Previous studies conducted in the Gaza Strip showed low awareness of symptoms as well as risk factors for both BC and CRC [10, 11]. Some educational initiatives were held by local universities and institutions. However, the effectiveness of these initiatives has not been measured to see their impact on people's knowledge about cancer. This study aimed to assess Gazans' awareness of: (i) the age-related risk and prevalence of cancer; (ii) cancer signs and symptoms; (iii) cancer risk factors, and to evaluate the differences in awareness between population groups, such as men and women as well as adults and adolescents.

\section{Materials And Methods Study Design and Population}

This was a cross-sectional study conducted from $1^{\text {st }}$ of September to $31^{\text {st }}$ of October, 2017. It assessed cancer awareness in the Gaza Strip and compared it between adolescents vs adults and females vs males. As an assessment tool, the Cancer Awareness Measure (CAM) questionnaire, which is a validated standardized measurement for cancer awareness in the general population, was used [12]. The questionnaire consisted of four sections; the first described the demographic data. The second evaluated the knowledge of cancer prevalence in Gaza and its age-related risk. The third comprised open-ended (recall) questions while the fourth included closed (recognition) questions allowing comparison between these two question types (recall vs recognition). A 3-point Likert scale was used to evaluate the knowledge of possible symptoms and warning signs of cancer. A 5-point Likert scale was used to assess the awareness of cancer risk factors. The CAM was translated from English to Arabic by two healthcare professionals with experience in health survey design and proficiency in both languages. Next it was back-translated into English by another two bilingual clinical researchers with similar experiences. Before starting data collection, a pilot study was conducted with 119 respondents to test the clarity of the questions of the Arabic version of the CAM.

A reliability analysis was carried out on the perceived task values scale comprising 16 items. Cronbach's alpha showed the questionnaire to reach acceptable reliability, $a=0.7$. Most items appeared to be worthy of retention, resulting in a decrease in the alpha if deleted. Although it has not been validated, a similar questionnaire was used in some previous studies conducted in Arabic-speaking countries [13-18].

\section{Sampling Methods}

Government hospitals are the main entry point for healthcare services in Gaza [10,11]. Therefore, adults, aged 18 years or over, admitted to or visiting those hospitals, were the target population and recruited to participate. Patients or visitors to oncology departments were excluded from the study. There are 13 
government hospitals in the Gaza Strip [19]. From these, the largest three hospitals, located in three separate geographical locations in the Gaza Strip were chosen for recruitment of participants by stratified sampling. This sampling area covered most of Gaza's population producing a geographically representative sample. In parallel to this, adolescents from ten high schools (out of 147 high schools in Gaza [20]), that were located in the same areas as the study hospitals, were recruited in order to achieve uniformity of areas. High school students are studying health-related topics in their curriculum, which gives the opportunity to explore their awareness of cancer. Participants were invited to face-to-face interviews for completion of the CAM. Data collectors were trained to recruit participants, distribute the questionnaires and facilitate completion. They were also trained to administer the questionnaire to illiterate participants.

\section{Statistical Methods}

Descriptive statistics were used for demographic data and the participants' knowledge of cancer prevalence and its age-related risk. Two open and unprompted questions regarding cancer signs/symptoms and risk factors were used to assess the participants' ability to recall a cancer symptom or risk factor without help from the interviewer.

The level of knowledge was determined by a scoring system that was used in previous studies in the United Kingdom and Malaysia [21, 22]. Each correctly recalled cancer sign/symptom or risk factor was given one point and incorrect answers were given a zero point. This resulted in a total score ranging from 0 to 8 , which was categorized into three categories; poor knowledge (0 to 2), fair knowledge (3 to 5), and good knowledge (6 to 8 ). Then, 16 closed questions (eight for cancer signs/symptoms and eight for cancer risk factors) were asked to evaluate the participant's recognition. A 3-point scale (no, I do not know, yes) was used to test the recognition of cancer signs/symptoms. Each correct answer (yes) was given one point and incorrect answers (no or do not know) were given no point. The total score was then calculated and was categorized using the same aforementioned scoring system. A 5-point Likert scale ( 1 = strongly disagree, 5 = strongly agree) was used to assess the recognition of cancer risk factors. Every correct answer (agree or strongly agree) was given one point, while other answers (strongly disagree, disagree or not sure) had no point. The total score for recognizing cancer risk factors was obtained and categorized in the same previously mentioned manner.

The variables of interest were the knowledge level of cancer signs, symptoms and risk factors. The chi-square test was used to compare the awareness of each cancer sign/symptom and risk factor as well as the knowledge level between the two sub-populations. Multiple logistic regression was used to test the association between gender and age-group with recalling cancer signs/symptoms and risk factors. It was also utilized to test their association with recognizing the symptoms. Ordinal regression was used to test the association of age-group and gender with recognizing risk factors. In addition, it was utilized to examine the association between the recall and recognition levels with gender and the age-group. Data were analyzed using Stata software version 15.0 (StataCorp, College Station, Texas, United States).

\section{Results}

\section{Characteristics of Participants:}

Of 3033 people who were invited to participate, 2886 participants completed the CAM questionnaire (response rate $=95.2 \%$ ). Among them, 1457 (50.5\%) were adolescent (781 females; $53.6 \%$ ) and 1429 (49.5\%) were adult (702 females; $49.1 \%$ ). The mean age of all participants was $24.9 \pm 11.9$ years (table 1 ).

Table 1: Summary of characteristics of the participants.

\begin{tabular}{|c|c|c|}
\hline characteristic & n (\%) & Mean age $( \pm \mathrm{SD})$ \\
\hline \multicolumn{3}{|l|}{ Gender } \\
\hline Male & 1403 (48.6) & $24.9( \pm 11.5)$ \\
\hline Female & 1483 (51.4) & $24.9( \pm 12.2)$ \\
\hline \multicolumn{3}{|l|}{ Age-group } \\
\hline Adolescent & 1457 (50.5) & $16.3( \pm 0.8)$ \\
\hline Adult & 1429 (49.5) & $33.7( \pm 11.4)$ \\
\hline Total & $2886(100.0)$ & $24.9( \pm 11.9)$ \\
\hline
\end{tabular}

$\mathrm{n}=$ number of participants tested, $\mathrm{SD}=$ standard deviation.

\section{Knowledge of Cancer Age-related Risk and Prevalence}

A total of 1885 participants (65.3\%) thought that cancer is unrelated to age and 112 (3.9\%) did not know if there was a relation at all (table 2). About 77.0\% $(n=2220)$ identified correctly BC as the most common cancer among women in Gaza. On the other hand, only 196 
participants (6.9\%) answered with CRC as the most common cancer among men in Gaza. Adult and male participants were more aware than adolescent and female participants in terms of recognizing the age-related risk and identifying the most common cancers in women and men in Gaza $(\mathrm{p}<0.001)$.

Table 2: Summary of knowledge of cancer age-related risk and its prevalence in Gaza

\begin{tabular}{|c|c|c|c|c|c|c|c|}
\hline Question & $\begin{array}{c}\text { Total } \\
(\mathrm{n}=2886) \\
\mathrm{n}(\%)\end{array}$ & $\begin{array}{c}\text { Adolescents } \\
(\mathrm{n}=1457) \\
\mathrm{n}(\%)\end{array}$ & $\begin{array}{c}\text { Adults } \\
(\mathrm{n}=1429) \\
\mathrm{n}(\%)\end{array}$ & $p$ value & $\begin{array}{c}\text { Females } \\
(\mathrm{n}=1483) \\
\mathrm{n}(\%)\end{array}$ & $\begin{array}{c}\text { Males } \\
(\mathrm{n}=1403) \\
\mathrm{n}(\%)\end{array}$ & $p$ value \\
\hline \multicolumn{8}{|c|}{ In the next year, who is most likely to develop cancer? } \\
\hline \multicolumn{8}{|l|}{20 's } \\
\hline 30 's & $260(9.0)$ & $104(7.1)$ & 156 (10.9) & $<0.001$ & 132 (8.9) & $128(9.1)$ & $<0.001$ \\
\hline 40 's & $175(6.1)$ & 54 (3.7) & $121(8.5)$ & & $88(5.9)$ & $87(6.2)$ & \\
\hline 50 's & $183(6.3)$ & $64(4.4)$ & $119(8.3)$ & & $82(5.5)$ & $101(7.2)$ & \\
\hline 60 's & $115(4.0)$ & $39(2.7)$ & $76(5.3)$ & & $49(3.3)$ & $66(4.7)$ & \\
\hline 70 's & $94(3.3)$ & $31(2.1)$ & $63(4.4)$ & & $33(2.2)$ & $61(4.3)$ & \\
\hline 80 's & $27(0.9)$ & $9(0.6)$ & $18(1.3)$ & & $10(0.7)$ & $17(1.2)$ & \\
\hline Cancer is unrelated to age & $35(1.2)$ & $6(0.4)$ & $29(2.0)$ & & $13(0.9)$ & $22(1.6)$ & \\
\hline \multirow[t]{2}{*}{ I do not know } & $1885(65.3)$ & 1047 (71.9) & $838(58.7)$ & & $1063(71.7)$ & $822(58.6)$ & \\
\hline & $112(3.9)$ & $103(7.1)$ & $9(0.6)$ & & $13(0.9)$ & $99(7.1)$ & \\
\hline \multicolumn{8}{|c|}{ What do you think is the most common cancer in women? } \\
\hline \multicolumn{8}{|l|}{ Breast cancer } \\
\hline Uterine cancer & $2220(76.9)$ & $981(67.3)$ & 1239 (86.7) & $<0.001$ & $1116(75.3)$ & 1104 (78.7) & 0.010 \\
\hline Cervical cancer & $63(2.2)$ & $29(2.0)$ & $34(2.4)$ & & $30(2.0)$ & $33(2.4)$ & \\
\hline Leukemia & $23(0.8)$ & $15(1.0)$ & $8(0.6)$ & & $9(0.6)$ & $14(1.0)$ & \\
\hline Colon cancer & $21(0.7)$ & $8(0.5)$ & $13(0.9)$ & & $6(0.4)$ & $15(1.1)$ & \\
\hline Others & $11(0.4)$ & $2(0.1)$ & $9(0.6)$ & & $6(0.4)$ & $5(0.4)$ & \\
\hline \multirow{2}{*}{ I do not know } & $37(1.3)$ & $16(1.2)$ & $21(1.5)$ & & $15(0.9)$ & $22(1.4)$ & \\
\hline & $511(17.7)$ & $406(27.9)$ & $105(7.3)$ & & 301 (20.3) & $210(15.0)$ & \\
\hline \multirow{2}{*}{\multicolumn{8}{|c|}{$\begin{array}{l}\text { What do you think is the most common cancer in men? } \\
\text { Lung cancer }\end{array}$}} \\
\hline & & & & & & & \\
\hline Prostate cancer & 620 (21.5) & 244 (16.7) & 376 (26.3) & $<0.001$ & 284 (19.2) & 336 (23.9) & $<0.001$ \\
\hline Leukemia & 627 (21.7) & 241 (16.5) & $386(27.0)$ & & 322 (21.7) & 305 (21.7) & \\
\hline Brain cancer & 245 (8.5) & $110(7.5)$ & 135 (9.4) & & $108(7.3)$ & 137 (9.8) & \\
\hline Colon cancer & $90(3.1)$ & $50(3.4)$ & $40(2.8)$ & & 49 (3.3) & $41(2.9)$ & \\
\hline Liver cancer & $196(6.8)$ & $33(2.3)$ & $163(11.4)$ & & $80(5.4)$ & $116(8.3)$ & \\
\hline Testicular cancer & $74(2.6)$ & $48(3.3)$ & $26(1.8)$ & & $34(2.3)$ & $40(2.9)$ & \\
\hline Others & $46(1.6)$ & $32(2.2)$ & $14(1.0)$ & & $26(1.8)$ & $20(1.4)$ & \\
\hline \multirow[t]{2}{*}{ I do not know } & $214(7.4)$ & $148(10.3)$ & $66(4.7)$ & & $100(6.7)$ & $114(8.1)$ & \\
\hline & $774(26.8)$ & 551 (37.8) & 223 (15.6) & & $480(32.3)$ & $294(21.0)$ & \\
\hline
\end{tabular}

$\mathrm{n}=$ number of participants tested.

In general, awareness of cancer symptoms/warning signs and its risk factors was low when open-ended (recall) questions were used and higher with closed (recognition) questions. Unexplained lump/swelling was the most commonly recognized cancer symptom ( $\mathrm{n}=2227$, $77.2 \%)$, while change of bowel habit was the least $(n=670,23.2 \%)$ (table 3). Adults demonstrated higher awareness than adolescents in recognizing all cancer signs and symptoms except 'unexplained pain'. This was also true after adjusting for gender (OR=0.77, 95\% CI: $0.66-0.89, \mathrm{p}=0.001$ ) (table 4). Only 347 participants (12.0\%) had a good level of recognizing cancer signs and symptoms; 277 adults $(19.4 \%)$ vs 70 adolescents (4.8\%) (table 5$)$.

There was a significant association between the age group and the level of recognition $(\mathrm{p}<0.001)$. The ordinal regression model showed that being adult increased the likelihood to have a higher recognition by $67.0 \%(\mathrm{OR}=1.67,95 \% \mathrm{CI}: 1.45-1.94$, p<0.001), which increased to $69.0 \%$ after the adjustment of gender (OR=1.69, 95\% CI: 1.46-1.96, p<0.001). In addition, gender had a significant association with the level of recognition ( $\mathrm{p}=0.031)$. In fact, females had a higher likelihood by $20.0 \%$ to have better recognition $(\mathrm{OR}=1.20$, $95 \%$ CI: 1.04 $1.38, \mathrm{p}=0.015)$, which went further up to $23.0 \%$ after adjusting for the age-group (OR=1.23, 95\% CI: 1.06-1.42, $\mathrm{p}=0.005)$. Women showed greater recognition of all cancer signs and symptoms except for 'persistent change in bowel habits'. This was also noticed after the adjustment for the age-group (OR=0.80, 95\% CI: 0.67-0.96, $\mathrm{p}=0.016)$.

\section{Awareness of Cancer Risk Factors}

Smoking was the most frequently recognized cancer risk factor $(n=2215,76.7 \%)$ and eating less than five portions of fruit and vegetables a day was the least ( $n=514,17.8 \%$ ) (table 6). Adults showed better recall and recognition of all cancer risk factors except for 
recalling 'smoking' and 'eating less than five portions of fruit and vegetables a day', where they were less likely than adolescents to recall them by $15.0 \%(\mathrm{OR}=0.85,95 \% \mathrm{CI}: 0.73-0.99, \mathrm{p}=0.041)$ and $14.0 \%(\mathrm{OR}=0.86,95 \% \mathrm{CI}: 0.74-0.99, \mathrm{p}=0.046)$ respectively, after the adjustment of gender (table 7). Only 217 participants (7.5\%) had a good level of recognizing cancer risk factors; 175 adults (12.2\%) vs 42 adolescents (2.8\%) (table 8 ). There was a significant association between the age-group and the level of recalling and recognizing cancer risk factors ( $\mathrm{p}=0.037$ and $<0.001$, respectively). After adjustment for gender, being adult increased the likelihood to have a higher recall and recognition than being adolescent by 1.54 (OR=1.54, 95\% CI: 1.04-2.29, p=0.032) and 2.15 times (OR=2.15, 95\% CI: $1.86-1.48$, $\mathrm{p}<0.001$ ) respectively. However, there was no independent association of gender with the level of recall and/or recognition.

\section{Discussion}

Basic knowledge of cancer risk factors, signs and symptoms is essential for early detection as well as early presentation to medical services. This is especially important in low-resource settings as the Gaza Strip, where no systematic screening program exists, and early presentation with symptoms is the main pathway to early diagnosis and potential cure in cancer treatment. The knowledge level of cancer symptoms and risk factors in Gaza ranged from poor to fair. A minority of the participants showed good level of recognition of cancer signs, symptoms and risk factors. However, when asking open questions to name cancer signs, symptoms or risk factors, all participants were very challenged and $>95 \%$ in all groups showed poor recall. Adults displayed higher awareness than adolescents and females demonstrated better knowledge than males.

In concordance with other studies, knowledge of cancer risk factors as well as signs and symptoms improved with age [10, 11, 23-26]. This is not surprising as informal learning through experiences in life and exposure to public education programs increases with age. Kyle et al. found that $66.9 \%$ of British adolescents (vs $71.9 \%$ in this study) believed cancer was not related to age [27]. Recently, the Palestinian Ministry of Health reported an increase of cancer incidence rates from 73.6 per 100,000 general population in 2012 to 89.0 in 2016 [2]. This increase has been a focus of discussion among the Gaza population and might possibly have led to the understanding of increasing cancer cases in all age groups. Furthermore, causes for increasing rates are still under investigation, but have been linked in the general public to the repeated wars on Gaza, increased awareness of the public and presentation to healthcare professionals with symptoms as well as increased awareness of possible signs and symptoms among doctors.

Similar to this study, adolescents and adults in previous studies most frequently reported unexplained mass/lump as a cancer symptom [17, 24, 27, 28]. This could be due to perceiving having a mass as a concerning sign of something unusual. It might also be linked to the linguistic link of 'tumour', which represents a mass, to cancer. However, less than $53 \%$ of both adults and adolescents recognized other cancer symptoms, which is similar to participants in China, India, the United Kingdom (UK) and Oman [17, 25, 29, 30]. Recognition of cancer symptoms was found to be similar in Australia, Canada, Denmark, Norway, Sweden and the UK, when investigated by the International Cancer Benchmarking Partnership [31]. However, survival rates varied with the UK and Denmark lagging behind. Reasons for this were thought to be greater barriers experienced by participants, resulting in later first presentation to the doctor [28, 32]. This in turn would increase the 'patient interval', the time elapsing from the first symptom to presentation to a doctor, leading to more advanced stages at the time of diagnosis [9, 32,33]. Therefore, reducing barriers for first presentation is as important as improving knowledge and awareness of cancer symptoms [9, 34-37]. Barriers can be emotional, like being worried about possible results, embarrassment or fear to see a doctor, service-related such as difficulty getting an appointment with a doctor, or practical like being too busy to see a doctor or difficulty with arranging transport [9-11]. However, negative beliefs also have a strong impact, such as the conviction that there is no cure for cancer or the treatment is worse than the actual disease $[24,34,35,37]$. Such negative thoughts have been found to vary greatly, within countries in different areas as well as among different countries, which has been coined the 'place effect'[36, 38, 39]. This 'place effect' might have an especially strong influence in the Gaza Strip, which is a geographically relatively isolated area, suffering from a 13-year siege, restricting travel and information exchange [40]. Furthermore, cancer remains connected to poor outcomes locally. Such beliefs might be a further factor promoting late presentation. When people believe that the visit to the doctor will not improve their outlook or prognosis, they are more likely to delay or avoid such visits [34, 35, 37].

Adolescents were extremely poor in recognition of cancer risk factors with only $2.8 \%$ having a good level of recognition. However, adults also showed poor recognition with $12.4 \%$ demonstrating a good level of knowledge. The discrepancy between the age groups was found despite the fact that health-related content had been introduced in schools over the last decades, raising expectations that adolescents might at least be nearly as good as adults in recognition of risk factors. The school curriculum content might be reflected in the fact that more adolescents than adults knew that 'smoking' and 'eating less than five portions of fruit and vegetables a day' were risk factors for cancer, both of which are facts actually 'taught' at school. In most studies 'smoking' was the most commonly recognized risk factor [18, 24, 25, 30, 41-43]. Smoking enjoyed worldwide high publicity as a cancer risk factor and it is interesting that adolescents were better at recognizing this risk factor than adults. However, except for smoking as a risk factor, general awareness rates were poor in this study compared to other studies, which showed proportions of $60-88 \%$ recognizing smoking, $21-50 \%$ recognizing 'eating less than five portions of fruit and vegetables a day' and around $30 \%$ recognizing the importance of exercise, compared to $76.7 \%, 17.8 \%$ and $25.0 \%$ respectively in this study [ $18,23,30,43]$. This discrepancy could be due to the fact that a number of awareness campaigns have been done on factors such as smoking, exercise and healthy diet in the localities of these other studies [28, 42,44-46]. However, so far, no sustained public awareness campaigns on the potential negative impact of modifiable lifestyle factors on cancer have been evaluated as to their impact on public knowledge or awareness in the Gaza Strip. Although around half of all cancer in the U.S. have been attributed to modifiable factors, such as smoking, lack of exercise and unhealthy diets by the American Cancer Society [47], this has not been translated into major interventions in low-income settings, such as Gaza. Therefore, an urgent need exists to include low- and middle-income countries in such efforts.

\section{Strengths and limitations}

This study took a large and representative sample from the Gaza population, including all five governorates. Moreover, it included adolescents from government schools, opening an unprecedented view on their awareness and knowledge around cancer. However, as this study aimed at assessing knowledge 
and awareness of cancer, it could not directly link awareness levels to actual outcomes. For this, another study design will be needed. Furthermore, adult participants were recruited from among hospital visitors which might have caused a degree of selection bias, as these people might have displayed a greater degree of health-seeking behaviour, possibly based on greater baseline health awareness.

Implications for practice

For greater impact, raising awareness has to be combined with careful promotion or reinforcement of positive beliefs and information of possible chances of cure $[35,37]$. Raising such awareness among adolescents could be a useful future investment and give an opportunity for early preventive measures. Kyle et al showed that a school-based educational intervention resulted in improving the recall and recognition of most of the cancer signs and symptoms even after six months from the intervention [27]. Such an intervention might be especially effective when combined with addressing negative beliefs. By reducing negative beliefs and increasing awareness in the younger age-group, a sustained effect on reduction of late presentation might be achieved, which could have a pronounced effect in low-resource settings, such as the Gaza Strip, in improving the quality of life and increasing survival of cancer sufferers. Currently, survival rates are poor in Palestine with 60\% of deaths due to breast cancer in 2016 (643 of 1072 deaths) having been judged as 'prematurely' [48]. Such poor survival has its main reasons in the lack of systematic and organized screening programs and late presentation to healthcare professionals. Therefore, educational intervention in younger age groups could make a fundamental difference to survival and quality of life in cancer patients in the Gaza Strip. Furthermore, interventions to improve public awareness of cancer symptoms have been shown to be more effective when delivered to individuals rather than with a population-based approach, such as in public awareness campaigns [26, 49-52]. Therefore, in low-resource settings, lacking systematic and wellorganized screening programs, where early diagnosis is essential to improve survival, a population-based approach should be combined with more tailored individualized education for better results $[34,37,45,49]$. The effects from such interventions could be pronounced and sustainable, when involving younger age groups, such as adolescents [25], as reflected in this study, by the better knowledge demonstrated by adolescents of some risk factors, included in their health-related school curriculum.

\section{Conclusions}

Both adults and adolescents in this low-income setting, the Gaza Strip, showed a big knowledge gap in the recognition of cancer risk factors and symptoms, when compared to studies from other high-income settings. However, information delivered in the school curriculum might have made an impact on adolescents' health-related knowledge. Therefore, combining the delivery of public campaigns as well as tailored knowledge to population groups, including the youth, will increase impact and sustainability and meet an urgent need of low- and middle-income countries.

\section{List Of Abbreviations}

$B C$ : Breast cancer

CRC: Colorectal cancer

CAM: Cancer awareness measure

Cl: $95 \%$ confidence interval

$O R$ : Odds ratio

UK: United Kingdom

US: United States

\section{Declarations}

\section{Ethics approval and consent to participate}

Ethical approval for this study was obtained from the Human Resources Department of the Palestinian Ministry of Health, which is the responsible body in Gaza to issue approvals for studies involving humans, as well as from the Ministry of Education and Higher Education, responsible for high schools in the Gaza Strip.

Prior to data collection, it was explained that participation was entirely voluntary and could be terminated at any time throughout the study. Written consent was obtained from all participants. All data were collected and kept confidential.

\section{Consent for publication}

Not applicable

\section{Availability of data and materials}

The dataset used and analyzed during the current study is available from the corresponding author on reasonable request. 


\section{Competing interests}

All authors declare no competing interests.

\section{Funding}

No funding was received for this paper.

\section{Authors' contributions}

ME contributed to design of the study, data collection, data analysis, data interpretation and drafting of the manuscript. $A E, N A, M A, I I, K A, M H, A Q, A A, H Y, H A$ $\mathrm{GM}, \mathrm{AAS}, \mathrm{AAL}, \mathrm{OB}, \mathrm{MEB}$ and TS contributed to data collection, entry and interpretation.

BB contributed to the design of the study, data interpretation, drafting of the manuscript, and supervision of the work. All authors have read and approved the final manuscript.

\section{Acknowledgements}

We appreciate all the feedback provided by Loai Albarqouni, MD, PhD, MSc. We would like to thank all participants who took part in the survey.

\section{References}

1.World Health Organization. Cancer Key Facts. http://www.who.int/en/news-room/fact-sheets/detail/cancer. Accessed 17 November, 2019.

2.Palestinian Ministry of Health. Cancer incidence in the Gaza Strip: Facts and Figures 2015-2016. http://www.moh.gov.ps/portal/wpcontent/uploads/2018/07/CANCER-IN-GAZA-2015-2016.pdf. Accessed 17 November, 2019.

3.Palestinian Ministry of Health. Annual Report for Healthcare in the Gaza Strip 2018; https://www.moh.gov.ps/portal/wp-content/uploads/2019/07/MOHAnnual-Report-2018-11-7-2019.pdf. Accessed 17 November, 2019.

4.Palestinian Ministry of Health. Health Annual Report in Palestine 2017. https://www.site.moh.ps/Content/Books/SqKowAFT5W8X4JiBEq9G7oxhDAj5kMzdy3ptPxXOpqK2DzurAO7A9f_1NTofLKiqyKkOVOlhEOjpD910KHIovSZk31vl Accessed 17 November, 2019.

5.Maringe C, Walters S, Rachet B, Butler J, Fields T, Finan P, et al. Stage at diagnosis and colorectal cancer survival in six high-income countries: a populationbased study of patients diagnosed during 2000-2007. Acta Oncol. 2013;52(5):919-32.

6.Moller H, Sandin F, Bray F, Klint A, Linklater KM, Purushotham A, et al. Breast cancer survival in England, Norway and Sweden: a population-based comparison. Int J Cancer. 2010;127(11):2630-8.

7.Moore MA, Sangrajrang S, Bray F. Asian Cancer Registry Forum 2014 - regional cooperation for cancer registration: priorities and challenges. Asian Pac $J$ Cancer Prev. 2014;15(5):1891-4.

8.Norwati D, Harmy MY, Norhayati MN, Amry AR. Colorectal cancer screening practices of primary care providers: results of a national survey in Malaysia. Asian Pac J Cancer Prev. 2014;15(6):2901-4.

9.Quaife SL, Forbes LJ, Ramirez AJ, Brain KE, Donnelly C, Simon AE, et al. Recognition of cancer warning signs and anticipated delay in help-seeking in a population sample of adults in the UK. Br J Cancer. 2014;110(1):12-8.

10.Elshami M, Abu Kmeil H, Abu-Jazar M, Mahfouz I, Ashour D, Aljamal A, et al. Breast Cancer Awareness and Barriers to Early Presentation in the Gaza-Strip: A Cross-Sectional Study. J Glob Oncol. 2018(4):1-13.

11.Elshami M, Alfaqawi M, Abdalghafoor T, Nemer AA, Ghuneim M, Lubbad H, et al. Public Awareness and Barriers to Seeking Medical Advice for Colorectal Cancer in the Gaza Strip: A Cross-Sectional Study. J Glob Oncol. 2019;5:JG01800252.

12.Stubbings S, Robb K, Waller J, Ramirez A, Austoker J, Macleod U, et al. Development of a measurement tool to assess public awareness of cancer. Br J Cancer. 2009;101 Suppl 2:S13-7.

13.Al Qadire M. Awareness of Cancer Signs and Barriers to Help Seeking: a National Survey. J Cancer Educ. 2018;33(6):1206-12.

14.Al Qadire M, Aljezawi M, Al-Shdayfat N. Cancer Awareness and Barriers to Seeking Medical Help Among Syrian Refugees in Jordan: a Baseline Study. J Cancer Educ. 2019;34(1):19-25.

15.Alawa J, Hamade O, Alayleh A, Fayad L, Khoshnood K. Cancer Awareness and Barriers to Medical Treatment Among Syrian Refugees and Lebanese Citizens in Lebanon. J Cancer Educ. 2019. 
16.Al-Azri M, Al-Hamedi I, Al-Awisi H, Al-Hinai M, Davidson R. Public awareness of warning signs and symptoms of cancer in oman: a community-based survey of adults. Asian Pac J Cancer Prev. 2015;16(7):2731-7.

17.Al-Azri M, Al-Maskari A, Al-Matroushi S, Al-Awisi H, Davidson R, Panchatcharam SM, et al. Awareness of Cancer Symptoms and Barriers to Seeking Medical Help Among Adult People Attending Primary Care Settings in Oman. Health Serv Res Manag Epidemiol. 2016;3:2333392816673290.

18.Al-Azri M, Al-Rasbi K, Al-Hinai M, Davidson R, Al-Maniri A. Awareness of risk factors for cancer among Omani adults-a community based study. Asian Pac J Cancer Prev. 2014;15(13):5401-6.

19.Palestinian Ministry of Health. Annual Report for Healthcare in the Gaza-Strip 2017. http://www.moh.gov.ps/portal/wp-content/uploads/2018/08/MOHAnnual-Report-2017-Final-9-9-2018.pdf. Accessed 11 November, 2019.

20.Palestinian Central Bureau of Statistics. Number of Schools in Palestine 2017. http://www.pcbs.gov.ps/Portals/_Rainbow/Documents/Education201601A.htm. Accessed 7 November, 2019.

21.Simon AE, Waller J, Robb K, Wardle J. Patient delay in presentation of possible cancer symptoms: the contribution of knowledge and attitudes in a population sample from the United kingdom. Cancer Epidemiol Biomarkers Prev. 2010;19(9):2272-7.

22.Su TT, Goh JY, Tan J, Muhaimah AR, Pigeneswaren Y, Khairun NS, et al. Level of colorectal cancer awareness: a cross sectional exploratory study among multi-ethnic rural population in Malaysia. BMC Cancer. 2013;13:376.

23.Power E, Simon A, Juszczyk D, Hiom S, Wardle J. Assessing awareness of colorectal cancer symptoms: measure development and results from a population survey in the UK. BMC Cancer. 2011;11:366.

24.Robb K, Stubbings S, Ramirez A, Macleod U, Austoker J, Waller J, et al. Public awareness of cancer in Britain: a population-based survey of adults. Br J Cancer. 2009;101 Suppl 2:S18-23.

25.Sharma D, Goel N, Sharma M, Walia D, Puri S. A community-based study on awareness of cancer and anticipated barriers in seeking help. 2019;5(1):61-5.

26. Whitaker KL, Scott SE, Wardle J. Applying symptom appraisal models to understand sociodemographic differences in responses to possible cancer symptoms: a research agenda. Br J Cancer. 2015;112 Suppl 1:S27-34.

27.Kyle RG, Forbat L, Rauchhaus P, Hubbard G. Increased cancer awareness among British adolescents after a school-based educational intervention: a controlled before-and-after study with 6-month follow-up. BMC Public Health. 2013;13(1):190.

28.Forbes LJ, Simon AE, Warburton F, Boniface D, Brain KE, Dessaix A, et al. Differences in cancer awareness and beliefs between Australia, Canada, Denmark, Norway, Sweden and the UK (the International Cancer Benchmarking Partnership): do they contribute to differences in cancer survival? Br $\mathrm{J}$ Cancer.

2013;108(2):292-300.

29.Liu Q, Zeng X, Wang W, Huang RL, Huang YJ, Liu S, et al. Awareness of risk factors and warning symptoms and attitude towards gastric cancer screening among the general public in China: a cross-sectional study. BMJ Open. 2019;9(7):e029638.

30.Shahab L, McGowan JA, Waller J, Smith SG. Prevalence of beliefs about actual and mythical causes of cancer and their association with sociodemographic and health-related characteristics: Findings from a cross-sectional survey in England. Eur J Cancer. 2018;103:308-16.

31.Forbes L, Simon A, Warburton F, Boniface D, Brain K, Dessaix A, et al. Differences in cancer awareness and beliefs between Australia, Canada, Denmark, Norway, Sweden and the UK (the International Cancer Benchmarking Partnership): do they contribute to differences in cancer survival? Br J Cancer. 2013;108(2):292-300.

32.Lyratzopoulos G, Abel GA, Brown CH, Rous BA, Vernon SA, Roland M, et al. Socio-demographic inequalities in stage of cancer diagnosis: evidence from patients with female breast, lung, colon, rectal, prostate, renal, bladder, melanoma, ovarian and endometrial cancer. Ann Oncol. 2013;24(3):843-50.

33.Neal RD, Tharmanathan P, France B, Din NU, Cotton S, Fallon-Ferguson J, et al. Is increased time to diagnosis and treatment in symptomatic cancer associated with poorer outcomes? Systematic review. Br J Cancer. 2015;112 Suppl 1:S92-107.

34.Hiom SC. Diagnosing cancer earlier: reviewing the evidence for improving cancer survival. Br J Cancer. 2015;112 Suppl 1:S1-5.

35.Hvidberg L, Wulff CN, Pedersen AF, Vedsted P. Barriers to healthcare seeking, beliefs about cancer and the role of socio-economic position. A Danish population-based study. Prev Med. 2015;71:107-13.

36.Niksic M, Rachet B, Warburton FG, Forbes LJ. Ethnic differences in cancer symptom awareness and barriers to seeking medical help in England. Br J Cancer. 2016;115(1):136-44.

37.Pedersen AF, Forbes L, Brain K, Hvidberg L, Wulff CN, Lagerlund M, et al. Negative cancer beliefs, recognition of cancer symptoms and anticipated time to help-seeking: an international cancer benchmarking partnership (ICBP) study. BMC Cancer. 2018;18(1):363. 
38.Macintyre S, Ellaway A, Cummins S. Place effects on health: how can we conceptualise, operationalise and measure them? Soc Sci Med. 2002;55(1):12539.

39.Nur U, Quaresma M, De Stavola B, Peake M, Rachet B. Inequalities in non-small cell lung cancer treatment and mortality. J Epidemiol Community Health. 2015;69(10):985-92.

40.UN Office of Humanitarian Affairs (OCHA). Humanitarian Atlas 2019. https://www.ochaopt.org/atlas2019/allmenu.html. Accessed 16 November, 2019.

41.Al-Sharbatti S, Muttappallymyalil J, Sreedharan J, Almosawy Y. Predictors of Colorectal Cancer Knowledge among Adults in the United Arab Emirates. Asian Pac J Cancer Prev. 2017;18(9):2355-9.

42.Power $\mathrm{E}$, Wardle J. Change in public awareness of symptoms and perceived barriers to seeing a doctor following Be Clear on Cancer campaigns in England. Br J Cancer. 2015;112 Suppl 1:S22-6.

43.Xu L, Odum M. Cancer Awareness and Behavioral Determinants Associated with Cancer Prevention-a Quantitative Study Among Young Adults in Rural Settings. J Cancer Educ. 2019;34(3):562-70.

44.Athey VL, Suckling RJ, Tod AM, Walters SJ, Rogers TK. Early diagnosis of lung cancer: evaluation of a community-based social marketing intervention. Thorax. 2012;67(5):412-7.

45.Ironmonger L, Ohuma E, Ormiston-Smith N, Gildea C, Thomson CS, Peake MD. An evaluation of the impact of large-scale interventions to raise public awareness of a lung cancer symptom. Br J Cancer. 2015;112(1):207-16.

46.Kennedy MPT, Cheyne L, Darby M, Plant P, Milton R, Robson JM, et al. Lung cancer stage-shift following a symptom awareness campaign. Thorax. 2018;73(12):1128-36.

47.American Cancer Society. Cancer Facts \& Figures. http://www.cancer.org/research/cancer-facts-statistics.html. Accessed 16 November, 2019.

48.Jubran J SA, Jarrar K, Hammad S. Pathway to Survival - the Story of Breast Cancer in Palestine 2018. https://palestine.unfpa.org/sites/default/files/pubpdf/Breast\%20Cancer\%20Report\%20Final_0.pdf. Accessed 16 November, 2019.

49.Anderson BO, Yip CH, Ramsey SD, Bengoa R, Braun S, Fitch M, et al. Breast cancer in limited-resource countries: health care systems and public policy. Breast J. 2006;12 Suppl 1:S54-69.

50.Austoker J, Bankhead C, Forbes LJ, Atkins L, Martin F, Robb K, et al. Interventions to promote cancer awareness and early presentation: systematic review. Br J Cancer. 2009;101 Suppl 2:S31-9.

51.Sung MR, Leighl NB. Improving lung cancer diagnosis: the evolving role of patients and care providers. J Thorac Dis. 2019;11(Suppl 3):S422-S4.

52.Taha H, Nystrom L, Al-Qutob R, Berggren V, Esmaily H, Wahlstrom R. Home visits to improve breast health knowledge and screening practices in a less privileged area in Jordan. BMC Public Health. 2014;14:428.

\section{Tables}

Table (3): Summary of awareness scores for cancer symptoms and signs between adolescents vs adults and between females vs males.

\begin{tabular}{|c|c|c|c|c|c|c|c|c|c|c|c|c|c|c|}
\hline \multirow[t]{3}{*}{ Symptom/sign } & \multicolumn{7}{|c|}{ Recall } & \multicolumn{7}{|c|}{ Recognition } \\
\hline & \multirow{2}{*}{$\begin{array}{c}\text { Total } \\
(\mathrm{n}= \\
2886) \\
\mathrm{n}(\%)\end{array}$} & \multicolumn{3}{|c|}{ Adolescents vs Adults } & \multicolumn{3}{|c|}{ Females vs Males } & \multirow{2}{*}{$\begin{array}{c}\text { Total } \\
(\mathrm{n}= \\
2886) \\
\mathrm{n}(\%)\end{array}$} & \multicolumn{3}{|c|}{ Adolescents vs Adults } & \multicolumn{3}{|c|}{ Females vs Males } \\
\hline & & $\begin{array}{l}\text { Adolescents } \\
\begin{array}{c}(\mathrm{n}=1457) \\
\mathrm{n}(\%)\end{array}\end{array}$ & $\begin{array}{c}\text { Adults } \\
(\mathrm{n}= \\
1429) \\
\mathrm{n}(\%)\end{array}$ & $\begin{array}{c}\mathrm{p} \\
\text { value }\end{array}$ & $\begin{array}{c}\text { Females } \\
(n= \\
1483) \\
n(\%)\end{array}$ & $\begin{array}{c}\text { Males } \\
(\mathrm{n}= \\
1403) \\
\mathrm{n}(\%)\end{array}$ & $\begin{array}{c}\mathrm{p} \\
\text { value }\end{array}$ & & $\begin{array}{l}\text { Adolescents } \\
\begin{array}{c}(\mathrm{n}=1457) \\
\mathrm{n}(\%)\end{array}\end{array}$ & $\begin{array}{c}\text { Adults } \\
(\mathrm{n}= \\
1429) \\
\mathrm{n}(\%)\end{array}$ & $\mathrm{p}$ value & $\begin{array}{c}\text { Females } \\
(n= \\
1483) \\
n(\%)\end{array}$ & $\begin{array}{c}\text { Males } \\
(\mathrm{n}= \\
1403) \\
\mathrm{n}(\%)\end{array}$ & $\begin{array}{c}\mathrm{p} \\
\text { value }\end{array}$ \\
\hline Unexplained swelling/lump & $\begin{array}{c}1145 \\
(39.7)\end{array}$ & $536(36.8)$ & $\begin{array}{c}609 \\
(42.6)\end{array}$ & 0.001 & $\begin{array}{c}690 \\
(46.5)\end{array}$ & $\begin{array}{c}455 \\
(32.4)\end{array}$ & $<0.001$ & $\begin{array}{c}2227 \\
(77.2)\end{array}$ & 1111 (76.3) & $\begin{array}{c}1116 \\
(78.1)\end{array}$ & 0.24 & $\begin{array}{c}1215 \\
(81.9)\end{array}$ & $\begin{array}{c}1012 \\
(72.1)\end{array}$ & $<0.001$ \\
\hline Unexplained pain & $\begin{array}{c}541 \\
(18.7)\end{array}$ & $310(21.3$ & $\begin{array}{c}231 \\
(16.2)\end{array}$ & $<0.001$ & $\begin{array}{c}285 \\
(19.2)\end{array}$ & $\begin{array}{c}256 \\
(18.2)\end{array}$ & 0.50 & $\begin{array}{r}1154 \\
(40.0)\end{array}$ & $629(43.2)$ & $\begin{array}{c}525 \\
(36.7)\end{array}$ & $<0.001$ & $\begin{array}{c}622 \\
(41.9)\end{array}$ & $\begin{array}{c}532 \\
(37.9)\end{array}$ & 0.027 \\
\hline Unexplained bleeding & $189(6.5)$ & $79(5.4)$ & $\begin{array}{r}110 \\
(7.7) \\
\end{array}$ & 0.013 & $\begin{array}{r}118 \\
(8.0) \\
\end{array}$ & $71(5.1)$ & 0.002 & $\begin{array}{r}1005 \\
(34.8) \\
\end{array}$ & $486(33.4)$ & $\begin{array}{r}519 \\
(36.3) \\
\end{array}$ & 0.10 & $\begin{array}{c}538 \\
(36.3) \\
\end{array}$ & $\begin{array}{c}467 \\
(33.3) \\
\end{array}$ & 0.09 \\
\hline $\begin{array}{l}\text { Persistent cough/ } \\
\text { hoarseness }\end{array}$ & $64(2.2)$ & $40(2.7)$ & $24(1.7)$ & 0.052 & $34(2.3)$ & $30(2.1)$ & 0.78 & $\begin{array}{c}892 \\
(30.9) \\
\end{array}$ & $344(23.6)$ & $\begin{array}{c}548 \\
(38.3) \\
\end{array}$ & $<0.001$ & $\begin{array}{c}462 \\
(31.2)\end{array}$ & $\begin{array}{c}430 \\
(30.6)\end{array}$ & 0.77 \\
\hline $\begin{array}{l}\text { Persistent change in bowel } \\
\text { habit }\end{array}$ & $66(2.3)$ & $18(1.2)$ & $48(3.4)$ & $<0.001$ & $32(2.2)$ & $34(2.4)$ & 0.63 & $\begin{array}{c}670 \\
(23.2) \\
\end{array}$ & $183(12.6)$ & $\begin{array}{c}487 \\
(34.1) \\
\end{array}$ & $<0.001$ & $\begin{array}{c}311 \\
(21.0) \\
\end{array}$ & $\begin{array}{c}359 \\
(25.6) \\
\end{array}$ & 0.003 \\
\hline $\begin{array}{l}\text { Persistent difficulty } \\
\text { swallowing }\end{array}$ & $35(1.2)$ & $14(1.0)$ & $21(1.5)$ & 0.21 & $18(1.2)$ & $17(1.2)$ & 0.99 & $\begin{array}{c}944 \\
(32.7)\end{array}$ & $398(27.3)$ & $\begin{array}{c}546 \\
(38.2)\end{array}$ & $<0.001$ & $\begin{array}{c}497 \\
(33.5)\end{array}$ & $\begin{array}{c}447 \\
(31.9) \\
\end{array}$ & 0.34 \\
\hline Non-healing ulcer & $34(1.2)$ & $29(2.0)$ & $5(0.3)$ & $<0.001$ & $22(1.5)$ & $12(0.9)$ & 0.12 & $\begin{array}{r}1127 \\
(39.1) \\
\end{array}$ & $545(37.4)$ & $\begin{array}{c}582 \\
(40.7) \\
\end{array}$ & 0.07 & $\begin{array}{c}569 \\
(38.4) \\
\end{array}$ & $\begin{array}{c}558 \\
(39.8) \\
\end{array}$ & 0.44 \\
\hline Unexplained weight loss & $\begin{array}{c}569 \\
(19.7)\end{array}$ & 217 (14.9) & $\begin{array}{c}352 \\
(24.6)\end{array}$ & $<0.001$ & $\begin{array}{c}307 \\
(20.7)\end{array}$ & $\begin{array}{c}262 \\
(18.7)\end{array}$ & 0.17 & $\begin{array}{r}1977 \\
(68.5)\end{array}$ & $974(66.8)$ & $\begin{array}{c}1003 \\
(70.2)\end{array}$ & 0.053 & $\begin{array}{c}1027 \\
(69.3)\end{array}$ & $\begin{array}{c}950 \\
(67.7)\end{array}$ & 0.37 \\
\hline
\end{tabular}

$\mathrm{n}=$ number of participants tested 
Table (4): The association of age group and gender with recalling and recognizing cancer symptoms.

\begin{tabular}{|c|c|c|c|c|c|c|c|c|}
\hline \multirow[t]{3}{*}{ Symptom/sign } & \multicolumn{4}{|c|}{ Recall $(n=2886)$} & \multicolumn{4}{|c|}{ Recognition $(n=2886)$} \\
\hline & \multicolumn{2}{|c|}{ Female gender } & \multicolumn{2}{|c|}{ Being adult } & \multicolumn{2}{|c|}{ Female gender } & \multicolumn{2}{|c|}{ Being adult } \\
\hline & $\begin{array}{c}{ }^{*} \text { Adjusted OR } \\
(95 \% \mathrm{CI})\end{array}$ & $\mathrm{p}$ value & $\begin{array}{c}{ }^{+} \text {Adjusted OR } \\
(95 \% \mathrm{CI})\end{array}$ & $\mathrm{p}$ value & $\begin{array}{c}{ }^{*} \text { Adjusted OR } \\
(95 \% \text { CI })\end{array}$ & $\mathrm{p}$ value & $\begin{array}{c}{ }^{+} \text {Adjusted OR } \\
(95 \% \mathrm{CI})\end{array}$ & $\mathrm{p}$ value \\
\hline Unexplained swelling/lump & $1.84(1.58-2.14)$ & $<0.001$ & $1.32(1.13-1.53)$ & $<0.001$ & $1.76(1.48-2.10)$ & $<0.001$ & $1.14(0.96-1.36)$ & 0.14 \\
\hline Unexplained pain & $1.05(0.87-1.27)$ & 0.61 & $0.71(0.59-0.86)$ & $<0.001$ & $1.17(1.01-1.36)$ & 0.040 & $0.77(0.66-0.89)$ & 0.001 \\
\hline Unexplained bleeding & $1.65(1.21-2.24)$ & 0.001 & $1.49(1.10-2.01)$ & 0.009 & $1.15(0.98-1.34)$ & 0.08 & $1.15(0.98-1.34)$ & 0.08 \\
\hline Persistent cough/ hoarseness & $1.05(0.64-1.73)$ & 0.85 & $0.61(0.36-1.01)$ & 0.06 & $1.06(0.90-1.24)$ & 0.49 & $2.02(1.72-2.37)$ & $<0.001$ \\
\hline Persistent change in bowel habit & $0.93(0.57-1.51)$ & 0.76 & $2.77(1.60-4.79)$ & $<0.001$ & $0.80(0.67-0.96)$ & 0.016 & $3.57(2.96-4.32)$ & $<0.001$ \\
\hline Persistent difficulty swallowing & $1.02(0.52-1.99)$ & 0.95 & $1.54(0.78-3.04)$ & 0.215 & $1.10(0.94-1.29)$ & 0.22 & $1.65(1.41-1.93)$ & $<0.001$ \\
\hline Non-healing ulcer & $1.64(0.81-3.34)$ & & $0.18(0.07-0.46)$ & $<0.001$ & $0.95(0.82-1.10)$ & 0.49 & $1.15(0.99-1.33)$ & 0.07 \\
\hline Unexplained weight loss & $1.17(0.97-1.42)$ & 0.09 & $1.88(1.56-2.27)$ & $<0.001$ & $1.08(0.92-1.27)$ & 0.33 & $1.17(1.01-1.37)$ & 0.049 \\
\hline
\end{tabular}

$\mathrm{n}=$ number of participants tested, $\mathrm{OR}=$ odds ratio, $\mathrm{CI}=$ confidence interval.

${ }^{*}$ Adjusted for age group, ${ }^{+}$Adjusted for gender.

Table (5): The level of knowledge of cancer symptoms and signs between adolescents vs adults and between females vs males.

\begin{tabular}{|c|c|c|c|c|c|c|c|c|c|c|c|c|c|c|}
\hline \multirow{3}{*}{$\begin{array}{c}\text { Knowledge } \\
\text { level }\end{array}$} & \multicolumn{7}{|c|}{ Recall } & \multicolumn{7}{|c|}{ Recognition } \\
\hline & \multirow{2}{*}{$\begin{array}{c}\text { Total } \\
(\mathrm{n}=2886) \\
\mathrm{n}(\%)\end{array}$} & \multicolumn{3}{|c|}{ Adolescents vs Adults } & \multicolumn{3}{|c|}{ Females vs Males } & \multirow{2}{*}{$\begin{array}{c}\text { Total } \\
(\mathrm{n}=2886) \\
\mathrm{n}(\%)\end{array}$} & \multicolumn{3}{|c|}{ Adolescents vs Adults } & \multicolumn{3}{|c|}{ Females vs Males } \\
\hline & & $\begin{array}{l}\text { Adolescents } \\
\begin{array}{c}(\mathrm{n}=1457) \\
\mathrm{n}(\%)\end{array}\end{array}$ & $\begin{array}{c}\text { Adults } \\
(\mathrm{n}=1429) \\
\mathrm{n}(\%)\end{array}$ & $\begin{array}{c}\mathbf{p} \\
\text { value }\end{array}$ & $\begin{array}{c}\text { Females } \\
(n=1483) \\
n(\%)\end{array}$ & $\begin{array}{c}\text { Males } \\
(n=1403) \\
n(\%)\end{array}$ & $\begin{array}{c}\mathrm{p} \\
\text { value }\end{array}$ & & $\begin{array}{l}\text { Adolescents } \\
\begin{array}{c}(\mathrm{n}=1457) \\
\mathrm{n}(\%)\end{array}\end{array}$ & $\begin{array}{c}\text { Adults } \\
(\mathrm{n}= \\
1429) \\
\mathrm{n}(\%) \\
\end{array}$ & p value & $\begin{array}{c}\text { Females } \\
(\mathrm{n}= \\
1483) \\
\mathrm{n}(\%)\end{array}$ & $\begin{array}{c}\text { Males } \\
(\mathrm{n}= \\
1403) \\
\mathrm{n}(\%)\end{array}$ & $\begin{array}{c}\mathrm{p} \\
\text { value }\end{array}$ \\
\hline Poor & $\begin{array}{l}2729 \\
(94.6)\end{array}$ & $1385(95.1)$ & $\begin{array}{l}1344 \\
(94.1)\end{array}$ & 0.23 & $\begin{array}{l}1397 \\
(94.2)\end{array}$ & $\begin{array}{l}1332 \\
(94.9)\end{array}$ & 0.38 & $\begin{array}{c}845 \\
(29.3)\end{array}$ & $449(30.8)$ & $\begin{array}{c}396 \\
(27.7)\end{array}$ & $<0.001$ & $\begin{array}{c}402 \\
(27.1)\end{array}$ & $\begin{array}{c}443 \\
(31.6)\end{array}$ & 0.031 \\
\hline Fair & $157(5.4)$ & $72(4.9)$ & $85(5.9)$ & & $86(5.8)$ & $71(5.1)$ & & $\begin{array}{c}1694 \\
(58.7)\end{array}$ & $938(64.4)$ & $\begin{array}{c}756 \\
(52.9)\end{array}$ & & $\begin{array}{c}896 \\
(60.4)\end{array}$ & $\begin{array}{c}798 \\
(56.9)\end{array}$ & \\
\hline Good & 0 & 0 & 0 & & 0 & 0 & & $\begin{array}{c}347 \\
(12.0)\end{array}$ & $70(4.8)$ & $\begin{array}{c}277 \\
(19.4)\end{array}$ & & $\begin{array}{c}185 \\
(12.5)\end{array}$ & $\begin{array}{c}162 \\
(11.5)\end{array}$ & \\
\hline
\end{tabular}

$\mathrm{n}=$ number of participants tested

Table (6): Summary of awareness scores for cancer risk factors between adolescents vs adults and between females vs males.

\begin{tabular}{|c|c|c|c|c|c|c|c|c|c|c|c|c|c|c|}
\hline \multirow[t]{3}{*}{ Risk factor } & \multicolumn{7}{|c|}{ Recall } & \multicolumn{7}{|c|}{ Recognition } \\
\hline & \multirow{2}{*}{$\begin{array}{c}\text { Total } \\
(\mathrm{n}= \\
2886) \\
\mathrm{n}(\%)\end{array}$} & \multicolumn{3}{|c|}{ Adolescents vs Adults } & \multicolumn{3}{|c|}{ Females vs Males } & \multirow{2}{*}{$\begin{array}{c}\text { Total } \\
(\mathrm{n}= \\
2886) \\
\mathrm{n}(\%)\end{array}$} & \multicolumn{3}{|c|}{ Adolescents vs Adults } & \multicolumn{3}{|c|}{ Females vs Males } \\
\hline & & $\begin{array}{l}\text { Adolescents } \\
\begin{array}{c}(\mathrm{n}=1457) \\
\mathrm{n}(\%)\end{array}\end{array}$ & $\begin{array}{c}\text { Adults } \\
(\mathrm{n}= \\
1429) \\
\mathrm{n}(\%)\end{array}$ & p value & $\begin{array}{c}\text { Females } \\
(n= \\
1483) \\
n(\%)\end{array}$ & $\begin{array}{c}\text { Males } \\
(\mathrm{n}= \\
1403) \\
\mathrm{n}(\%)\end{array}$ & $\begin{array}{c}\mathrm{p} \\
\text { value }\end{array}$ & & $\begin{array}{l}\text { Adolescents } \\
\begin{array}{c}(\mathrm{n}=1457) \\
\mathrm{n}(\%)\end{array}\end{array}$ & $\begin{array}{c}\text { Adults } \\
(\mathrm{n}= \\
1429) \\
\mathrm{n}(\%)\end{array}$ & p value & $\begin{array}{c}\text { Females } \\
(\mathrm{n}= \\
1483) \\
\mathrm{n}(\%)\end{array}$ & $\begin{array}{c}\text { Males } \\
(\mathrm{n}= \\
1403) \\
\mathrm{n}(\%)\end{array}$ & $\mathrm{p}$ value \\
\hline Smoking & $\begin{array}{r}1027 \\
(35.6)\end{array}$ & $542(37.2)$ & $\begin{array}{c}485 \\
(33.9)\end{array}$ & 0.07 & $\begin{array}{c}469 \\
(31.6)\end{array}$ & $\begin{array}{c}558 \\
(39.8)\end{array}$ & $<0.001$ & $\begin{array}{r}2215 \\
(76.7)\end{array}$ & $1102(75.6)$ & $\begin{array}{r}1113 \\
(77.9)\end{array}$ & 0.16 & $\begin{array}{l}1200 \\
(80.9)\end{array}$ & $\begin{array}{r}1015 \\
(72.3)\end{array}$ & $<0.001$ \\
\hline Passive smoking & $\begin{array}{c}75 \\
(2.6)\end{array}$ & $29(2.0)$ & $\begin{array}{c}46 \\
(3.2)\end{array}$ & 0.046 & $44(3.0)$ & $\begin{array}{c}31 \\
(2.2)\end{array}$ & 0.24 & $\begin{array}{r}1544 \\
(53.5)\end{array}$ & $738(50.7)$ & $\begin{array}{c}806 \\
(56.4)\end{array}$ & 0.002 & $\begin{array}{c}815 \\
(55.0)\end{array}$ & $\begin{array}{c}729 \\
(52.0)\end{array}$ & 0.11 \\
\hline $\begin{array}{l}\text { Eating less than } 5 \text { portions of fruit and } \\
\text { vegetables a day }\end{array}$ & $\begin{array}{r}1086 \\
(37.6)\end{array}$ & $578(39.7)$ & $\begin{array}{c}508 \\
(35.5)\end{array}$ & 0.023 & $\begin{array}{c}647 \\
(43.6)\end{array}$ & $\begin{array}{c}439 \\
(31.3)\end{array}$ & $<0.001$ & $\begin{array}{c}514 \\
(17.8)\end{array}$ & $202(13.9)$ & $\begin{array}{c}312 \\
(21.8)\end{array}$ & $<0.001$ & $\begin{array}{c}270 \\
(18.2)\end{array}$ & $\begin{array}{c}244 \\
(17.4)\end{array}$ & 0.59 \\
\hline Being overweight & $\begin{array}{c}93 \\
(3.2)\end{array}$ & $45(3.1)$ & $\begin{array}{c}48 \\
(3.4)\end{array}$ & 0.75 & $58(3.9)$ & $\begin{array}{c}35 \\
(2.5)\end{array}$ & 0.035 & $\begin{array}{r}1201 \\
(41.6)\end{array}$ & $525(36.0)$ & $\begin{array}{c}676 \\
(47.3)\end{array}$ & $<0.001$ & $\begin{array}{c}630 \\
(42.5)\end{array}$ & $\begin{array}{c}571 \\
(40.7)\end{array}$ & 0.35 \\
\hline Getting sunburnt more than once as a child & $\begin{array}{c}38 \\
(1.3) \\
\end{array}$ & $14(1.0)$ & $\begin{array}{c}24 \\
(1.7)\end{array}$ & 0.10 & $17(1.1)$ & $\begin{array}{c}21 \\
(1.5) \\
\end{array}$ & 0.42 & $\begin{array}{c}536 \\
(18.6)\end{array}$ & $200(13.7)$ & $\begin{array}{c}336 \\
(23.5)\end{array}$ & $<0.001$ & $\begin{array}{c}278 \\
(18.7)\end{array}$ & $\begin{array}{c}258 \\
(18.4)\end{array}$ & 0.81 \\
\hline Being over 70 years old & $\begin{array}{c}31 \\
(1.1)\end{array}$ & $6(0.4)$ & $\begin{array}{c}25 \\
(1.7)\end{array}$ & $<0.001$ & $16(1.1)$ & $\begin{array}{c}15 \\
(1.1)\end{array}$ & 0.98 & $\begin{array}{c}731 \\
(25.3)\end{array}$ & $48(17.0)$ & $\begin{array}{c}483 \\
(33.8)\end{array}$ & $<0.001$ & $\begin{array}{c}355 \\
(23.9)\end{array}$ & $\begin{array}{c}376 \\
(26.8)\end{array}$ & 0.08 \\
\hline Having a close relative with cancer & $\begin{array}{l}212 \\
(7.3)\end{array}$ & $76(5.2)$ & $\begin{array}{c}136 \\
(9.5)\end{array}$ & $<0.001$ & $\begin{array}{c}124 \\
(8.4) \\
\end{array}$ & $\begin{array}{c}88 \\
(6.3) \\
\end{array}$ & 0.032 & $\begin{array}{c}980 \\
(34.0)\end{array}$ & $383(26.3)$ & $\begin{array}{c}597 \\
(41.8)\end{array}$ & $<0.001$ & $\begin{array}{c}527 \\
(35.5)\end{array}$ & $\begin{array}{c}453 \\
(32.3)\end{array}$ & 0.07 \\
\hline $\begin{array}{l}\text { Doing less than } 30 \text { minutes of moderate } \\
\text { physical activity } 5 \text { times a week }\end{array}$ & $\begin{array}{c}37 \\
(1.3)\end{array}$ & $16(1.1)$ & $\begin{array}{c}21 \\
(1.5)\end{array}$ & 0.41 & $18(1.2)$ & $\begin{array}{c}19 \\
(1.4)\end{array}$ & 0.74 & $\begin{array}{c}722 \\
(25.0)\end{array}$ & $355(24.4)$ & $\begin{array}{c}367 \\
(25.7)\end{array}$ & 0.42 & $\begin{array}{c}349 \\
(23.5)\end{array}$ & $\begin{array}{c}373 \\
(26.6)\end{array}$ & 0.06 \\
\hline
\end{tabular}


Table (7): The association of age-group and gender with recalling and recognizing cancer risk factors.

\begin{tabular}{|c|c|c|c|c|c|c|c|c|}
\hline \multirow[t]{3}{*}{ Risk factor } & \multicolumn{4}{|c|}{ Recall $(n=2886)$} & \multicolumn{4}{|c|}{ Recognition ( $n=2886$ ) } \\
\hline & \multicolumn{2}{|c|}{ Female gender } & \multicolumn{2}{|c|}{ Being adult } & \multicolumn{2}{|c|}{ Female gender } & \multicolumn{2}{|c|}{ Being adult } \\
\hline & $\begin{array}{c}{ }^{*} \text { Adjusted OR } \\
(95 \% \mathrm{CI})\end{array}$ & $\begin{array}{c}\mathrm{p} \\
\text { value }\end{array}$ & $\begin{array}{c}{ }^{+} \text {Adjusted OR } \\
(95 \% \mathrm{CI})\end{array}$ & $\begin{array}{c}\mathrm{p} \\
\text { value }\end{array}$ & $\begin{array}{c}{ }^{*} \text { Adjusted OR } \\
(95 \% \mathrm{CI})\end{array}$ & $\begin{array}{c}\mathrm{p} \\
\text { value }\end{array}$ & $\begin{array}{c}{ }^{+} \text {Adjusted } \\
\text { OR } \\
(95 \% \mathrm{CI})\end{array}$ & $\begin{array}{c}\mathrm{p} \\
\text { value }\end{array}$ \\
\hline Smoking & $\begin{array}{c}0.70(0.60- \\
0.81)\end{array}$ & $<0.001$ & $\begin{array}{c}0.85(0.73- \\
0.99)\end{array}$ & 0.041 & $\begin{array}{c}1.63(1.37- \\
1.94)\end{array}$ & $<0.001$ & $\begin{array}{c}1.16(0.98- \\
1.38)\end{array}$ & 0.09 \\
\hline Passive smoking & $\begin{array}{c}1.38(0.87- \\
2.21)\end{array}$ & 0.17 & $\begin{array}{c}1.66(1.04- \\
2.66)\end{array}$ & 0.035 & $\begin{array}{c}1.14(0.98- \\
1.32)\end{array}$ & 0.08 & $\begin{array}{c}1.27(1.10- \\
1.47)\end{array}$ & 0.002 \\
\hline Eating less than 5 portions of fruit and vegetables a day & $\begin{array}{c}1.69(1.45- \\
1.97)\end{array}$ & $<0.001$ & $\begin{array}{c}0.86(0.74- \\
0.99)\end{array}$ & 0.046 & $\begin{array}{c}1.08(0.89- \\
1.31)\end{array}$ & 0.41 & $\begin{array}{c}1.74(1.43- \\
2.12)\end{array}$ & $<0.001$ \\
\hline Being overweight & $\begin{array}{c}1.60(1.04- \\
2.45)\end{array}$ & 0.031 & $\begin{array}{c}1.11(0.74- \\
1.68)\end{array}$ & 0.61 & $\begin{array}{c}1.10(0.95- \\
1.28)\end{array}$ & 0.21 & $\begin{array}{c}1.60(1.38- \\
1.86)\end{array}$ & $<0.001$ \\
\hline Getting sunburnt more than once as a child & $\begin{array}{c}0.78(0.41- \\
1.49)\end{array}$ & 0.45 & $\begin{array}{c}1.74(0.90- \\
3.38)\end{array}$ & 0.10 & $\begin{array}{c}1.05(0.87- \\
1.28)\end{array}$ & 0.58 & $\begin{array}{c}1.94(1.60- \\
2.35)\end{array}$ & $<0.001$ \\
\hline Being over 70 years old & $\begin{array}{c}1.07(0.53- \\
2.17)\end{array}$ & 0.86 & $\begin{array}{c}4.32(1.77- \\
10.57)\end{array}$ & 0.001 & $\begin{array}{c}0.89(0.75- \\
1.06)\end{array}$ & 0.18 & $\begin{array}{c}2.48(2.08- \\
2.95) \\
\end{array}$ & $<0.001$ \\
\hline Having a close relative with cancer & $\begin{array}{c}1.41(1.06- \\
1.87)\end{array}$ & 0.019 & $\begin{array}{c}1.94(1.45- \\
2.60)\end{array}$ & $<0.001$ & $\begin{array}{c}1.20(1.02- \\
1.40)\end{array}$ & 0.023 & $\begin{array}{c}2.03(1.74- \\
2.38)\end{array}$ & $<0.001$ \\
\hline $\begin{array}{l}\text { Doing less than } 30 \text { minutes of moderate physical activity } 5 \\
\text { times a week }\end{array}$ & $\begin{array}{l}0.91(0.47- \\
1.74)\end{array}$ & 0.77 & $\begin{array}{l}1.34(0.69- \\
2.58)\end{array}$ & 0.38 & $\begin{array}{l}0.85(0.72- \\
1.01)\end{array}$ & 0.06 & $\begin{array}{l}1.07(0.90- \\
1.26)\end{array}$ & 0.46 \\
\hline
\end{tabular}

$\mathrm{n}=$ number of participants tested, $\mathrm{OR}=$ odds ratio, $\mathrm{CI}=$ confidence interval.

${ }^{*}$ Adjusted for age group, ${ }^{+}$Adjusted for gender.

Table (8): The level of knowledge of cancer risk factors between adolescents vs adults and between females vs males.

\begin{tabular}{|c|c|c|c|c|c|c|c|c|c|c|c|c|c|c|}
\hline \multirow{3}{*}{$\begin{array}{c}\text { Knowledge } \\
\text { level }\end{array}$} & \multicolumn{7}{|c|}{ Recall } & \multicolumn{7}{|c|}{ Recognition } \\
\hline & \multirow{2}{*}{$\begin{array}{c}\text { Total } \\
(\mathrm{n}=2886) \\
\mathrm{n}(\%)\end{array}$} & \multicolumn{3}{|c|}{ Adolescents vs Adults } & \multicolumn{3}{|c|}{ Females vs Males } & \multirow{2}{*}{$\begin{array}{c}\text { Total } \\
(\mathrm{n}=2886) \\
\mathrm{n}(\%)\end{array}$} & \multicolumn{3}{|c|}{ Adolescents vs Adults } & \multicolumn{3}{|c|}{ Females vs Males } \\
\hline & & $\begin{array}{l}\text { Adolescents } \\
\begin{array}{c}(\mathrm{n}=1457) \\
\mathrm{n}(\%)\end{array}\end{array}$ & $\begin{array}{c}\text { Adults } \\
(\mathrm{n}=1429) \\
\mathrm{n}(\%)\end{array}$ & $\begin{array}{c}\mathrm{p} \\
\text { value }\end{array}$ & $\begin{array}{c}\text { Females } \\
(n=1483) \\
n(\%)\end{array}$ & $\begin{array}{c}\text { Males } \\
(n=1403) \\
n(\%)\end{array}$ & $\begin{array}{c}\mathrm{p} \\
\text { value }\end{array}$ & & $\begin{array}{l}\text { Adolescents } \\
\begin{array}{c}(\mathrm{n}=1457) \\
\mathrm{n}(\%)\end{array}\end{array}$ & $\begin{array}{c}\text { Adults } \\
(n= \\
1429) \\
n(\%)\end{array}$ & $p$ value & $\begin{array}{c}\text { Females } \\
(n= \\
1483) \\
n(\%)\end{array}$ & $\begin{array}{c}\text { Males } \\
(\mathrm{n}= \\
1403) \\
\mathrm{n}(\%)\end{array}$ & $\begin{array}{c}\mathrm{p} \\
\text { value }\end{array}$ \\
\hline Poor & $\begin{array}{l}2780 \\
(96.3) \\
\end{array}$ & $1414(97.1)$ & $\begin{array}{c}1366 \\
(95.6) \\
\end{array}$ & 0.037 & $\begin{array}{c}1420 \\
(95.8) \\
\end{array}$ & $\begin{array}{c}1360 \\
(96.9) \\
\end{array}$ & 0.09 & $\begin{array}{c}1254 \\
(43.5) \\
\end{array}$ & $747(51.3)$ & $\begin{array}{c}507 \\
(35.5) \\
\end{array}$ & $<0.001$ & $\begin{array}{c}626 \\
(42.2) \\
\end{array}$ & $\begin{array}{c}628 \\
(44.8) \\
\end{array}$ & 0.26 \\
\hline Fair & $106(3.7)$ & $43(2.9)$ & $63(4.4)$ & & $63(4.2)$ & $43(3.1)$ & & $\begin{array}{c}1415 \\
(49.0)\end{array}$ & $668(45.9)$ & $\begin{array}{c}747 \\
(52.3)\end{array}$ & & $\begin{array}{c}749 \\
(50.5)\end{array}$ & $\begin{array}{c}666 \\
(47.5)\end{array}$ & \\
\hline Good & 0 & 0 & 0 & & 0 & 0 & & $217(7.5)$ & $42(2.8)$ & $\begin{array}{c}175 \\
(12.2)\end{array}$ & & $\begin{array}{l}108 \\
(7.3)\end{array}$ & $\begin{array}{l}109 \\
(7.7)\end{array}$ & \\
\hline
\end{tabular}

$\mathrm{n}=$ number of participants tested 